\title{
The Fashion Industry and its Problematic Consequences in the Green Marketing Era - a Review
}

\author{
Nikola Sagapova ${ }^{1, *}$, Roman Buchtele ${ }^{2}$, Radim Dušek ${ }^{1}$ \\ ${ }^{1}$ Institute of Technology and Business, Faculty of Corporate Strategy, Okruzni 517/10, 37001 Ceske Budejovice, Czech Republic \\ ${ }^{2}$ University of South Bohemia, Faculty of Economics, Studentska 13, 37005 Ceske Budejovice, Czech Republic
}

\begin{abstract}
This paper uses a narrative literature review to provide evidence of the problematic consequences of the fast fashion industry in the context of sustainability and to consider the option of the green marketing approach as a way of reducing negative impacts. Studies relevant to our research were identified through a search of Web of Science, Science Direct, Scopus and Google Scholar. In recent years, environmental sustainability has played an important role on the political agenda, but it is also driving innovation in business. The range of environmentally friendly products on the market is increasing, and consumers are showing interest in buying these types of products, which are usually more expensive. Unfortunately, fashion production is one of the least sustainable industries. Therefore, more and more fashion companies are trying to implement green approaches in their value chains. Green marketing in the context of the fashion industry essentially refers to products that are produced with respect to working conditions and the environment, and to the possibility of finding a compromise between business objectives and environmental issues.
\end{abstract}

Keywords: green marketing; fashion industry; environment; sustainability; CSR

\section{Introduction}

With the public's growing interest in the environment since the 1960s and companies' interest in improving their image through their environmental efforts, marketing communication in the form of green marketing is increasingly being used to appeal to environmentally conscious consumers [1]. Companies have realised that consumers are beginning to make environmentally conscious purchases. The increasing interest of consumers, politicians, investors and companies in the environment has led to a greening of business and the emergence of a new marketing concept known as 'green marketing'. It is marketing's response to the environmental impact of the "design, production, packaging, use and disposal of products" [2]. While in the initial phase of the development of 'ecological' green marketing, the focus was concentrated on specific environmental problems such as air and water pollution, excessive use of natural resources and dependence on products that are partially harmful to the environment. In the second phase of the development of 'environmental' green marketing, marketers focused more on reducing environmental damage through green consumer demand and competitive advantages for companies in the market. In the third phase of 'sustainable' green marketing, thanks to increased consumer awareness of global issues and the links between the environment, society and the economy, marketing targets sustainability and reflects the total environmental cost in product prices to create a sustainable economy and society [3]. There is a similar, but motivationally different classification and designation of the concept as environmental marketing, within which three different approaches emerged - ecological, green and sustainable marketing. The motivations for ecological marketing are moral impulses and a positive attitude towards the environment; green marketing is motivated by market pressure and sustainable marketing is motivated by the companies' long-term perspective on value preservation and profits, seeking a compromise between business objectives and environmental issues [4]. While environmental sustainability has taken an important role on the political agenda, it is also driving innovation in business. The number of environmentally friendly products that are available on the market is increasing and consumers are showing a growing interest in buying them and are willing to pay a higher price [5].

On the other hand, pseudo-green companies are entering the market to gain a competitive advantage through greenwashing practices without real concern and efforts for environmental protection [6]. Companies that engage in greenwashing attempt to convince consumers that the company or its products are environmentally friendly, when in fact they have a poor environmental performance, while at the same time communicating their good environmental performance. Such behaviour harm the consumer and investor trust in companies with products that actively care for the environment [7], leads to consumer confusion [8] and has a negative impact on green purchases, green brand image and loyalty even among environmentally conscious consumers $[9,10]$. Moreover, greenwashing is widespread in the fashion and textile industry [11]. These industries are also questionable in terms of sustainability and corporate social

\footnotetext{
* Corresponding author: sagapova@mail.vstecb.cz
} 
responsibility (CSR) as such [12] and have been criticised for exploiting human and natural resources, environmental degradation, pollution and waste [13].

From an existential perspective, sustainability and sustainable production and consumption is no longer a luxury or a choice, but a necessity [14]. Therefore, this paper aims to obtain evidence of problematic consequences of the fast fashion industry in the sustainability context and to review the option of the green marketing approach as a way to reduce the negative impacts.

\section{Methodology}

This study uses a narrative literature review to gather available evidence of the consequences of the fashion industry in the sustainability context and its common practices and findings related to green marketing approaches. This method is preferred due to its possibility to find enough information, including the criticism, on a given topic in a relatively short time framework. Another reason for choosing this method is the perceived lack of information about the reality and the dark side of this industry within the scientific publications. To find relevant research studies, we defined the search topics. Based on previous expert opinions and background information, we start with the introduction of fast fashion and socioeconomic, ethical and environmental contexts in the modern fashion industry. Then we continue with green marketing and sustainability in fast fashion to get a complete and perhaps critical overview of the issue and find possible gaps in current research and understanding of environmental awareness and moreover sustainability in this industry. Studies relevant to our research were identified through a search of Web of Science, Science Direct, Scopus and Google Scholar. The search period was not limited.

\section{Results and Discussion}

\subsection{Fast fashion}

The fashion industry has changed its dynamics in recent decades. The modern clothing market is dominated by 'fast fashion', which drives new trends, increases the number of fashion seasons and frequency of consumption, shortens the usability of items with no long-term value, and establishes offshore supply chains with cheap manufacturing to deliver large quantities of clothing quickly and at low cost to be priced competitively [15-18]. In the last two decades, fashion supply chains have shifted to developing countries, recently from Asia to Africa, promising socio-economic development to these countries, but ultimately fast fashion comes with a higher cost [19]. Due to production problems, and other economic, social, ethical and environmental impacts, companies are trying to promote and ensure sustainability in their value chains to improve performance, set sustainability criteria and conduct monitoring and auditing activities [20]. However, the audits are often ineffective, even fictitious, and do not reveal the actual unsatisfactory conditions $[21,22]$.

\subsubsection{Fast fashion and its socio-economic, ethical and environmental context}

While the market pushes the industry to make clothes even cheaper, to cut corners, this has consequences in the form of declining product quality, and negative social and environmental effects [23]. The entire life cycle of inexpensive clothing involves risks to people and the environment, who bear the costs [24]. The key element for low-cost fashion production is cheap labour, which can be found in developing countries [20]. Cheap labour is associated with low wages and poor working conditions [24]. Extensive violations of workers' and human rights, long working hours, child labour and exposure to chemicals are commonplace in this industry [25]. Large companies are in a position to cut corners to make the greatest possible profit [26]. In this context, the global structure of industry almost forces companies to cut production costs by squeezing out suppliers, moving production abroad and contracting it out to workshops that also employ informal workers to gain a competitive advantage, but in this case, this international competition is more of a race to the bottom [27]. The textile and fashion industry is often criticised for involving practices of modern slavery [28]. Shifting production to developing countries lowers costs not only because of cheap labour and exploitation of human rights but also because of the lack of adequate social, environmental, safety and other legal standards regulating the fashion sector, making it the least regulated and least sustainable global industry [29,30]. The textile and fashion industry is one of the largest employers, but also the second-largest polluter after the oil industry [31]. The dyeing and processing of textiles produce a lot of heavily polluted wastewater, the discharge of which into the river is prohibited for environmental reasons [32]. However, in developing countries like Bangladesh, these polluted effluents are also recently discharged into rivers and streams to save the high costs of treatment chemicals and energy-intensive technologies [33]. This also leads to the pollution of surface water, groundwater and soils, causing significant negative externalities and affecting the lives of poor people and the livelihoods of farmers who own and cultivate polluted soils that lose value and fertility [34]. In contrast, cotton-based textiles require large amounts of water and pesticides, while polyester, for example, is made from petroleum [24]. Our clothing also releases chemicals and micro textile waste, and in the case of synthetic materials, microplastics can eventually enter the food chain. Due to the throwaway culture of fast fashion, over $2 / 3$ of our textiles end up in landfills [35]. The fast fashion industry is obviously very wasteful and far from being sustainable or closed-loop, and clothing itself has gone from being a durable good to a daily purchase thanks to the fast fashion 
production system and business model [36]. One of the characteristics of the fast fashion industry is the limited protection of intellectual property, which often tempts designers to copy the designs and products of others [37].

Moreover, various accidents related to factories, such as the fire at the Tazreen factory in 2012 or the collapse of the Rana Plaza building in 2013. It was built without permits and serious examination of the building's statics and yet produced clothes for 29 mostly world-renowned brands. Even though a huge crack was discovered a day before the collapse, all people, mostly women and children, were forced to stay at their workplaces. Not just these tragedies have raised concerns about the functioning of the fast fashion system. Some other factories were later closed because of their poor construction. In addition to such accidents in industry, there have also been cases of unpaid wages for workers who work in factories producing goods for brands such as Zara, Next and Mango [38]. While fast fashion allows products to be delivered to retailers in a matter of weeks to meet consumer demand for new garments, overconsumption, industry practices and growing awareness of environmental and social consequences are providing the impetus for new ways of producing and consuming fashion [39]. The counterpart to fast fashion is so-called slow fashion, which promotes sustainable production and consumption of fashion [40]. However, fast fashion companies have also started to launch sustainable collections to increase the legitimacy of the company, the perception of CSR and trust in the brand in the eyes of customers [41]. Policymakers could promote sustainability in fast fashion through interventions, taxes or subsidies, as awareness of sustainability does not automatically lead to sustainable economic behaviour; customers should be more aware and update their knowledge so that they are not misled by false marketing communication from different fast fashion brands [42].

\subsection{Green marketing and sustainability in fast fashion industry}

Sustainability and ethics in the context of the fashion industry essentially refer to products that are manufactured with respect for working conditions and the environment, which can be a part of CSR [43]. The responsibility for sustainable fashion lies not only with the fashion industry, which must create conditions for sustainable production and remanufacturing, green marketing and green information exchange but also with fashion consumers, who can have a green attitude and improve their awareness, knowledge and education [42]. Marketing should provide a basis to encourage consumers to make sustainable purchasing decisions for longer-lasting quality clothing made from appropriate materials in appropriate production processes [44]. Yet, fast fashion is characterised by an increase in clothing consumption and a decrease in the trend cycle. It is also typical that consumers from the middle class buy these clothes, which are fashionable and cheap at the same time. However, the empirical results show the general trend that consumers have a greater awareness of environmental issues [45]. Unfortunately, consumers may not be aware of the costs of cheap fashion and the excesses of fast fashion need to be highlighted and communicated by policymakers, industry players and various stakeholders to guide consumers towards more sustainable fashion that fast fashion and its production, sourcing, design, marketing and consumption [37]. If sustainability is a goal, the fast fashion industry needs to change its practices and integrate marketing strategies that encompass the entire marketing mix (4 P's), resulting in reshaping the industry, reducing consumption, frequency of purchases, setting higher prices, less discounting, fewer collections per year, limiting the number of physical shops, extending the life of products through higher quality, active promoting of sustainability and value to reduce overconsumption and lower environmental impact [14]. Currently, consumer behaviour may also be influenced to some extent by the COVID 19 global pandemic. Fast fashion retailers use e-commerce solutions as their predominant business model at the time of the pandemic, so fast fashion clothing is easily available despite the situation [46]. The global impact of the fast fashion industry in terms of carbon emissions is enormous. Fast fashion production has doubled this century, resulting in a $30 \%$ increase in carbon emissions. This may suggest that the sector is becoming greener to some extent, but an absolute improvement in the environmental impact of fashion could be achieved by eliminating fast fashion as a business model [47].

The most common research is on the proper strategy of fast fashion companies. The aim is mainly to maximise profits or sales. An effective marketing strategy that could be explored by fast fashion marketers is linked to green marketing. As studied in Indonesia, companies that engage in green marketing and innovate their products can influence customers' willingness to make indirect purchases in the future through the company's image and CSR. From the consumers' perspective, the results show that CSR is the most important factor motivating consumers to make purchases as they are increasingly interested and concerned about the environment and sustainability [48]. Green marketing in fashion and claims such as organic or recycled fibres, sustainable manufacturing, donations to green organisations, fair trade and labour practices can increase companies' profits by reducing consumers' price sensitivity and increasing their willingness to pay [49]. However, based on research that focused on specifying the marketing strategy of fast fashion retailers in relation to consumer attitudes towards the sustainability of fast fashion products in the UK, one consumer segment was defined as not receptive to fast fashion products with sustainability attributes - the working-class female in the United Kingdom. Furthermore, this is a large segment in the UK. It was also found that among consumers of fast fashion products, their claimed knowledge of sustainability is likely to be higher than their actual knowledge because they are overconfident [42]. Fast fashion merchandisers also frequently enter into partnerships with non-governmental organisations (NGOs). They use this strategy mainly to mitigate negative reactions from environmentally-conscious consumer groups. The effects of such partnerships may be beneficial at first glance, but there is a good chance that they will fail and harm both parties. Fast fashion companies pursue a business model that aims to maximise profits, while NGOs cater to the higher social and environmental demands of the public. The partnership between fast fashion companies and NGOs has the 
advantage of increasing adaptability to change, flexibility, innovation and securing their own organisational identity. Obstacles may lie mainly in the area of possible opportunism and lack goal orientation [50].

Consumer behaviour in fast fashion from a sustainability perspective can also be looked at from the other side, i.e., the consumer side. The sustainable characteristics of products positively influence consumer behaviour in the fast fashion sector. On the other hand, consumer behaviour is more likely to be associated with positive implicit attitudes when sustainability is paired with luxury than with fast fashion. It was also confirmed that sustainability influences a higher level of perceived warmth. This also has a positive effect on consumer behaviour towards fast fashion products [51]. Some sustainable marketing activities play a key role in constructing a positive image of fast fashion and brand image. These might be economic, environmental, cultural and social activities, which can through improved image help the brand to survive on the market [52]. With luxury clothing, one can also observe the cultural environment in which the retailer operates. Sustainable communication for non-luxury apparel brands is more effective in a cultural environment characterised by higher awareness related to sustainability [53]. Similarly, environmentally conscious consumers pay more attention to content-based than associative environmental claims in advertising and respond more to communications from luxury brands than fast fashion brands, even though both luxury and fast fashion products are unsustainable and harmful to the environment [54].

\section{Conclusion}

The fashion industry is undoubtedly a key industry and one of the largest employers worldwide, but on the other hand, it is also one of the least sustainable industries in the world. The relocation of production to developing countries due to cost-cutting in many cases leads to the exploitation of human rights and the lack of adequate social, environmental, safety and other legal standards. Furthermore, the fashion industry is very wasteful and produces a lot of heavily polluted wastewater, so it is far from being an example of a sustainable industry. The reasons for this are obvious. Fast fashion dominates the clothing market of the 21 st century. Fast fashion means increasing consumption, shortening the useful life of items supplied in large quantities and reducing manufacturing costs to increase price competitiveness.

In recent years, environmental sustainability has played an important role in the political agenda, but it is also driving innovation in business. The supply of environmentally friendly products on the market is increasing and consumers are showing interest in buying these types of products, which tend to be higher priced. Due to the aforementioned negative impacts, more and more fashion companies are trying to implement green marketing approaches in their value chains to improve performance and meet desired sustainability criteria. Green marketing in the context of the fashion industry essentially refers to products that are manufactured with respect to working conditions and the environment, which can be a part of CSR to find a compromise between business objectives and environmental issues. The sustainable approaches in the fashion industry are not only the responsibility of the main companies but also of the consumers, who should improve their awareness, knowledge and education on green attitudes. Effective green marketing should lay the foundation for changing clothing consumption and encourage consumers to make sustainable purchasing decisions for longer-lasting quality clothing made from appropriate materials in appropriate production processes.

\section{References}

1. S. Szabo, J. Webster. Perceived Greenwashing: The Effects of Green Marketing on Environmental and Product Perceptions. Journal of Business Ethics. 171, 719-739 (2021)

2. M. Lampe, G. M. Gazda. Green marketing in Europe and the United States: An evolving business and society interface. International Business Review. 4(3), 295-312 (1995)

3. K. Peattie. Towards sustainability: the third age of green marketing. The Marketing Review. 2, 129-146 (2001)

4. Y. K. van Dam, P. A. X. Apeldoorn. Sustainable Marketing. Journal of Macromarketing. 16, 56-56 (1996)

5. R. M. Dangelico, D. Vocalelli. "Green Marketing”: An analysis of definitions, strategy steps, and tools through a systematic review of the literature. Journal of Cleaner Production, 164, 1263-1279 (2017)

6. D. Jog, D. Singhal. Pseudo green payers and their greenwashing practices: a differentiating strategy for real green firms of personal care category. Strategic Direction. 35(12), 4-7 (2019)

7. M. A. Delmas, V. C. Burbano. The Drivers of Greenwashing. California Management Review. 54(1), 64-87 (2011)

8. Y.-S. Chen, C.-H. Chang. Greenwash and Green Trust: The Mediation Effects of Green Consumer Confusion and Green Perceived Risk. Journal of Business Ethics. 114, 489-500 (2013)

9. I. Hameed, Z. Hyder, M. Imran. Greenwash and green purchase behavior: an environmentally sustainable perspective. Environment, Development and Sustainability. 23, 13113-13134 (2021)

10. E.-J. Lee, H. Choi, J. Han, D. H. Kim, E. Ko, K. H. Kim. How to "Nudge" your consumers toward sustainable fashion consumption: An fMRI investigation. Journal of Business Research. 117, 642-651 (2020) 
11. G. Kaner. Greenwashing: How Difficult It Is to Be Transparent to the Consumer - H\&M Case Study. In: C. Mukonza, R. E. Hinson, O. Adeola, I. Adisa, E. Mogaji, A. C. Kirgiz. Green Marketing in Emerging Markets. Cham: Palgrave Macmillan (2021)

12. D. Zimon, P. Madzik. The Influence of ISO 9001 \& ISO 14001 on Sustainable Supply Chain Management in the Textile Industry. Sustainability. 12(10), 4282 (2020)

13. C. D'Souza, A. J. Gilmore, P. Hartmann, V. A. Ibáñez, G. Sullivan-Mort. Male eco-fashion: a market reality. International Journal of Consumer Studies. 39(1), 35-42 (2015)

14. R. Ciornea. Is the Transition to Bioeconomy a Sustainable Solution in Fast-fashion Industry, Considering the Overconsumption? - Premises for Future Research. MID Journal. 3(1), 27-44 (2020)

15. V. Bhardwaj, A. Fairhust. Fast fashion: response to changes in the fashion industry. The International Review of Retail, Distribution and Consumer Research. 20(1), 165-173 (2010)

16. S. A. Doyle, C. M. Moore, L. Morgan. Supplier management in fast fashion moving fashion retailing. Journal of Fashion Marketing and Management. 13(3), 272-281 (2006)

17. K. Niinimäki, G. Peters, H. Dahlbo, P. Perry, T. Rissanen, A. Gwilt. The environmental price of fast fashion. Nature Reviews Earth \& Environment. 1, 189-200 (2020)

18. A. Joy, J. F. Sherry Jr., A. Venkatesh, J. Wang, R. Chan. Fast Fashion, Sustainability, and the Ethical Appeal of Luxury Brands. Fashion Theory. 16(3), 273-295 (2012)

19. K. Khurana, S. S. Muthu. Are low- and middle-income countries profiting from fast fashion? Journal of Fashion Marketing and Management. doi:org/10.1108/JFMM-12-2020-0260 (2021)

20. D. Turker, C. Altuntas. Sustainable supply chain management in the fast fashion industry: An analysis of corporate reports. European Management Journal. 32(5), 837-849 (2014)

21. A. F. Borthick, M. B. Curtis. Due Diligence on Fast-Fashion Inventory through Data Querying. Journal of Information Systems. 22(1), 77-93 (2008)

22. A. G. Woodside, M. B. Fine. Sustainable fashion themes in luxury brand storytelling: The sustainability fashion research grid. Journal of Global Fashion Marketing. 10(2), 111-128 (2019)

23. C. E. Henninger, M. Blazquez, R. Boardman, C. Jones, H. McCormick, S. Sahab. Cradle-To-Cradle Versus Consumer Preferences. In: The Fashion Industry. In S. Hashmi, A. I, Choudhury. Encyclopedia of Renewable and Sustainable Materials. Oxford: Elsevier (2020)

24. R. Bick, E. Halsey, C. C. Ekenga. The global environmental injustice of fast fashion. Environmental Health. 17, 92 (2018)

25. J. Hobson. To die for? The health and safety of fast fashion. Occupational Medicine. 63(5), 317-319 (2013)

26. M. N. Cruz. Is Fast Fashion a Concern of the Everyday Teen? Student Research Symposium. 8 (2017)

27. J. M. Bressán. From Neoliberal Fashion to New Ways of Clothing. Socialist Register 2021. 57, 201-217 (2021)

28. A. V. Benstead, L. C. Hendry, M. Stevenson. Horizontal collaboration in response to modern slavery legislation: An action research project. International Journal of Operations \& Production Management. 38(12), 2286-2312 (2018)

29. X. Cherny-Scanlon, K. Agnes, Time for a Responsible Fashion Council? In S. Muthu, M. Gardetti (Eds.) Green Fashion: Environmental Footprints and Eco-design of Products and Processes (123-150), Springer, Singapore, (2016).

30. A. Clarke-Sather, K. Cobb. Onshoring fashion: Worker sustainability impacts of global and local apparel production. Journal of Cleaner Production. 208, 1206-1218 (2019)

31. A. K. Pattanayak. Sustainability in fabric manufacturing. In: R. Nayak. Sustainable Technologies for Fashion and Textiles. Amsterdam: Elsevier (2020)

32. S. Sondhi. Sustainable approaches in effluent treatment: Recent developments in the fashion manufacturing. In: R. Nayak. Sustainable Technologies for Fashion and Textiles. Amsterdam: Elsevier (2020)

33. N. R. Khandaker, I. Afreen, D. S. Diba, F. B. Huq, T. Akter. Treatment of textile wastewater using calcium hypochlorite oxidation followed by waste iron rust aided rapid filtration for color and COD removal for application in resources challenged Bangladesh. Groundwater for Sustainable Development. 10, 100342 (2020)

34. T. S. Devi, C. Ramasamy, S. Gurunathan. Farmers' Willingness to Pay to Avert the Negative Externalities of Pollution of Dyeing Industry in Tamil Nadu. Agricultural Economics Research Review. 23(2), 245-252 (2010) 
35. K. Shirvanimoghaddam, B. Motamed, S. Ramakrishna, M. Naebe. Death by waste: Fashion and textile circular economy case. Science of The Total Environment. 718, 137317 (2020)

36. T. Brydges. Closing the loop on take, make, waste: Investigating circular economy practices in the Swedish fashion industry. Journal of Cleaner Production. 293, 126245 (2021)

37. M. K. Brewer. Slow Fashion in a Fast Fashion World: Promoting Sustainability and Responsibility. Laws. 8, 24 (2019)

38. T. Sádaba, P. SanMiguel, P. Gargoles. Communication Crisis in Fashion: From the Rana Plaza Tragedy to the Bravo Tekstil Factory Crisis. In: N. Kalbaska, T. Sádaba, T. Cominelli, F. Cantoni. Fashion Communication in the Digital Age. Switzerland: Springer (2019)

39. A. Buzzo, M. J. Abreu. Fast Fashion, Fashion Brands \& Sustainable Consumption. In: S. S. Muthu. Fast Fashion, Fashion Brands and Sustainable Consumption. Singapore: Springer (2019)

40. T. Chi, J. Gerard, Y. Yu, Y. Wang. A study of U.S. consumers' intention to purchase slow fashion apparel: understanding the key determinants. International Journal of Fashion Design, Technology and Education. 14(1), 101-112 (2021)

41. G. Miotto, S. Youn. The impact of fast fashion retailers' sustainable collections on corporate legitimacy: Examining the mediating role of altruistic attributions. Journal of Consumer Behaviour. 19(6), 618-631 (2020)

42. B. Zhang, Y. Zhang, P. Zhou. Consumer Attitude towards Sustainability of Fast Fashion Products in the UK. Sustainability. 13, 1646 (2021)

43. B. Shen, Y. Wang, C. Lo, M. Shum. The impact of ethical fashion on consumer purchase behaviour. Journal of Fashion Marketing and Management. 16, 234-245 (2012)

44. H. Goworek, L. Oxborroe, S. Claxton, A. McLaren, T. Cooper, H. Hill. Managing sustainability in the fashion business: Challenges in product development for clothing longevity in the UK. Journal of Business Research. 117, 629-641 (2020)

45. J. Jang, E. Ko, E. Chun, E. Lee. A Study of a Social Content Model for Sustainable Development in the Fast Fashion Industry. Bridging Fashion and Marketing. 3(2), 61-70 (2012)

46. K. Bilińska-Reformat, A. Dewalska-Opitek. E-commerce as the predominant business model of fast fashion retailers in the era of global COVID 19 pandemics. Procedia Computer Science. 192, 2479-2490 (2021)

47. G. Peters, M. Li, M. Lenzen. The need to decelerate fast fashion in a hot climate - A global sustainability perspective on the garment industry. Journal of Cleaner Production. 295, 126390 (2021)

48. G. D. Tulangow, K. A. Kusumawardani. Green is the new black: the role of green marketing awareness and perceived innovation in the fast fashion industry. The 4th International Conference on Family Business and Entrepreneurship [online]. Available 2 at: https://ejournal.president.ac.id/presunivojs/index.php/ICFBE/article/viewFile/1373/746 (2020)

49. C. Stall-Meadows, A. Davey. Green marketing of apparel: consumers' price sensitivity to environmental marketing claims. Journal of Global Fashion Marketing. 4(1), 33-43 (2013)

50. S. Y. H. Liu, E. Napier, A. Runfola, S. T. Cavusgil. MNE-NGO partnerships for sustainability and social responsibility in the global fast-fashion industry: A loose-coupling perspective. International Business Review. 29(5), $101736(2020)$

51. L. Grazzini, D. Acuti, G. Aiello. Solving the puzzle of sustainable fashion consumption: The role of consumers' implicit attitudes and perceived warmth. Journal of Cleaner Production. 287, 125579 (2021)

52. J. Jung, S. J. Kim, K. H. Kim. Sustainable marketing activities of traditional fashion market and brand loyalty. Journal of Business Research. 120, 294-301 (2020)

53. H. M. Kong, A. Witmaier, E. Ko. Sustainability and social media communication: How consumers respond to marketing efforts of luxury and non-luxury fashion brands. Journal of Business Research. 131, 640-651 (2021)

54. T. Gogichaishvili, K. Enju, J. K. Sang. Environmental claims in online video advertising: effects for fast-fashion and luxury brands. International Journal of Advertising. 39(6), 1-30 (2019) 